\title{
Potentials and challenges of sustainable taro (Colocasia esculenta) production in Nigeria
}

\author{
Alfred O. Ubalua ${ }^{1}$, Favour Ewa ${ }^{2}$, Onyinyechi D. Okeagu ${ }^{3}$ \\ ${ }^{1}$ Plant Tissue Culture Unit, Biotechnology Research and Development Center, National Root Crops Research Institute (NRCRI) Umudike, P.M.B 7006 \\ Umuahia, Abia State, Nigeria. ${ }^{2}$ Molecular Biology Unit, Biotechnology Research and Development Center, National Root Crops Research Institute \\ (NRCRI) Umudike, P.M.B 7006 Umuahia, Abia State, Nigeria. ${ }^{3}$ Yam Programme, National Root Crops Research Institute (NRCRI) Umudike, P.M.B 7006 \\ Umuahia, Abia State, Nigeria.
}

\section{ARTICLE INFO}

Article history:

Received on: 03/10/2015

Revised on: 01/11/2015

Accepted on: 06/12/2015

Available online: 19/02/2016

Key words:

Taro, minute granules, medical nutrition therapy, industrial crop.

\begin{abstract}
During the past years, precisely 1965-1980, yam and taro reigned supreme in the Southern parts of Nigeria. Yam was the king and taro the queen. They were then the staple food of choice and were even offered to the gods. Their acceptance and ascendancy were challenged by the arrival and domestication of the easy growers (plantain, banana, maize and later cassava, tannia and sweet potato). The easy growers gained recognition and prominence as staple foods and subsequently replaced the earlier staples. Thus, cassava and sweet potato superseded yam and taro respectively. Nutritionally, taro has broader compliments of vitamins and nutrients compared to other root and tuber crops. The domestication of the new crops which are relatively more yielding and at the same time enjoys international leverage in research and development pose enormous challenges for the future of taro as a major crop. Strategic options for increase in taro production and consumption should be on consumer education and on its nutritional and health benefits. Increased attention on taro research will provoke a better understanding and contributions the crop can offer in the areas of food security, health and economic empowerment. The paper now reviews some of the nutritional and medicinal benefits of taro. Its contributions as an industrial crop will also be highlighted with special emphasis on the challenges facing taro crop cultivation in Nigeria and the possible approaches to enhance its sustainable production.
\end{abstract}

\section{INTRODUCTION}

Taro, dasheen, old cocoyam or Colocasia esculenta Schott is a member of the Araceae family grown for its edible corms, cormels and leaves. Commonly known as taro, it is a staple vegetable crop that has been used as food for over 9,000 years making it one of the world's oldest food crops [1]. Taro is one of the most widespread of the root and tuber crops cultivated almost everywhere throughout the tropics [2]. Although toxic when raw like most cassava cultivars, edible when cooked, it has been acclaimed to have medicinal properties [3]. It is a lowland crop presumably because it is temperature sensitive and has high demand for moisture for their production probably because of their large transpiring surfaces [4]. Taro grows best in humid environments and most varieties do not tolerate drought. The crop can grow up to about 1-2 meters in height and produces

* Corresponding Author

Email: alfreduba@yahoo.com heart-shaped leaves. An annual rainfall of approximately $250 \mathrm{~cm}$ is recommended, although, they can be grown in upland areas where the rainfall is about $175 \mathrm{~cm}$ provided it is evenly distributed throughout the growing period. While high rainfall is needed during the first 20 weeks growth period corresponding to the period of maximum leaf development, thereafter drier conditions can be tolerated until harvest [5]. Sunitha et al., [4] contends that there is a close relationship between rainfall received during $4^{\text {th }}, 5^{\text {th }}$ and $6^{\text {th }}$ month period, which coincides with tuber bulking in taro. Hence, tuber bulking stage has been considered as the most critical period of water deficit stress in taro production. Under moisture deficit stress, taro shows significant reduction in leaf production, while tannia (Xanthosoma sagittifolium) manifests only a slight reduction in leaf number. Taro has a shallow root system and the majority of the roots are confined to a lateral spread of $40 \mathrm{~cm}$ and depth of 9 $\mathrm{cm}$ in the soil [6]. It responds well to $\mathrm{N}, \mathrm{P}$ and $\mathrm{K}$ applications and is sometimes grown as a monocrop but is also widely planted in multiple cropping systems with other root crops including bananas, 
plantains and tree crops. Although the crop is not tolerant to salinity, however, it prefers slightly acidic growing conditions $(\mathrm{pH}$ 5.5-6.5) [7]. In addition, taro's establishment can be improved under shade, even though production is higher when exposed to direct sunlight in later stages of growth. Under flooded conditions, rice, lotus and taro are among the few crops in the world that can be grown successfully with optimum yield [4]. Sunell and Arditti, [8] posited that the large air space in the petiole of taro permits the submerged parts to maintain gaseous exchange with the atmosphere and that the greater yield associated with flooding is attributed to a greater ability to produce suckers and to greater surface area of the leaves. Consequently, the rate of leaf senescence under flooding condition is lower.

The growth and development cycle of taro crop can be divided into three main periods. Growth during the first two months is slow. This period begins with the sprouting of shoot and ends when the corms emerge. Corm formation commences at about three months after planting, while cormel formation follows soon afterwards in cultivars that produce appreciable cormels [9]. The second period is characterized by a rapid increase in shoot growth till 6-7 months after planting (MAP) during which maximum leaf areas, pseudo stem diameter and height of the plant is achieved [10]. By the end of the sixth month when shoot growth gradually declines, the corm and cormels become the main sink and grow very rapidly [9]. As the adverse (dry) season sets in, shoot growth declines until they finally dies back, characterizing the third period. Although taros are very adaptable, they need a rich soil for their optimum development and yield. When grown under less than ideal conditions, they respond well to mulching [11] or to applications of nitrogen, phosphorus and potassium, especially the first [12-13]. Under good conditions and with good varieties, yields of up to 15 tons/acre (about 38 tonnes/ha) can be obtained although experiments in Hawaii have given yields of nearly 50 tonnes/ha on heavily fertilized plots [13].

Taro does not compete well with weeds during the first 3 months of its establishment. Another drawback is its susceptibility to a number of pests and diseases including taro leaf blight, plant leaf hoppers, caterpillars, mites and cocoyam root rot disease [7][14]. Traditionally, taro is vegetatively propagated but may also reproduce sexually [15]. Deo et al., [16]) opined that its propagation through vegetative/clonal method is responsible for the plant's poor genetic variation within the cultivars while the occurrence of somatic mutations within the cultivars predisposes their vulnerability to pest and diseases [15]. Although sexual hybridization in taro has been documented and techniques for pollinating and growing seedlings have been established [17-18], this technique is labour intensive and time consuming. Moreover, the germination and planting of seedlings and screening processes take several years. A conservative estimate of 10 years or more is needed from the time pollination is initiated till the new, improved cultivar finally reaches a large number of farmers [16]. However, viable seed production depends on the availability and compatibility of resistant germplasms as well as the vagaries of weather and pests and diseases [19]. Several researchers have reported on the production of improved taro cultivars through tissue culture [20-21]. Similarly, de novo regeneration in taro has also been reported and documented [22-23]. Moreover, production of improved taro varieties via genetic transformation offers an attractive alternative to conventional breeding. This technique was successfully carried out using both Agrobacterium tumefaciens and microprojectile bombardment of regenerable embryogenic suspension [24-27] and regenerable callus [28-29]. It is therefore hopeful that these biotechnology alternatives may offer positive solutions to the contrasting reports on the dormancy and viability of taro seeds produced by sexual hybridization [2][30] and other associated production problems of taro.

\section{THE POTENTIALS AND UNIQUENESS OF TARO}

Food has always been one of man's foremost biological needs and its nutritional value depends on its digestibility, nutritional content and the presence or absence of anti nutrients and toxins factors [31]. Taro crop is largely cultivated because of its underground corms and cormels (Figs. 1A \& B). The corm contains about $70-80 \%$ starch. The minute size of the starch granules accounts for its excellent digestibility with the concomitant efficient release of nutrients during digestion and absorption [31]. Nutritionally, taro has broader compliments of vitamins and nutrients than other root and tuber crops [32]. Table 1 shows the proximate compositional pattern of taro. Besides considerable amount of starch, taro is also rich in vitamin $\mathrm{C}$, and has been reported to be rich in calcium, phosphorus, and potassium which are important constituents of human diets [32].

Table 1: Proximate composition of the taro corm (Colocasia esculenta) on fresh weight basis.

\begin{tabular}{cc}
\hline Component & Content \\
\hline Moisture & $63-85 \%$ \\
Carbohydrate (mostly starch) & $13-29 \%$ \\
Protein & $1.4-3.0 \%$ \\
Fat & $0.16-0.36 \%$ \\
Crude fibre & $0.60-1.18 \%$ \\
Ash & $0.60-1.3 \%$ \\
Vitamin C & $7-9 \mathrm{mg} / 100 \mathrm{~g}$ \\
Thiamine & $0.18 \mathrm{mg} / 100 \mathrm{~g}$ \\
Riboflavin & $0.04 \mathrm{mg} / 100 \mathrm{~g}$ \\
Niacin & $0.9 \mathrm{mg} / 100 \mathrm{~g}$ \\
\hline
\end{tabular}

Source: Onwueme, 1994

Taro corms has been reported to contain high contents of potassium and magnesium in the range 2,251-4,143 $\mathrm{mg} / 100 \mathrm{~g}$ and $118-219 \mathrm{mg} / 100 \mathrm{~g}$ dry matter respectively [33] but low in calories [32]. The dry matter of taro corm is generally higher than in other root crops [34-35]. The crop taro is unique in many ways. The digestibility of taro starch has been estimated to be 98.8 percent [36-37]. Its starch grain size and ease of assimilation accounts for its use by persons with digestive problems and extensively for infant formulae [2][37][38]. Credited to be a special substitute for persons allergic to cereals and can be consumed by children who are sensitive to milk [39-40], its higher vitamin content has also proven to be effective against tooth decay and lower incidences of acute or sub acute infection of gums [2][37][41]. Taro flour is a 
specific example of untapped potential in processed form. Taro flour could be mixed with wheat flour to make bread. Considering the geometric increase in bread consumption throughout the developing world and the sudden increase in wheat importation in Nigeria, the need to intensify its use with wheat therefore warrants serious investigation [42].

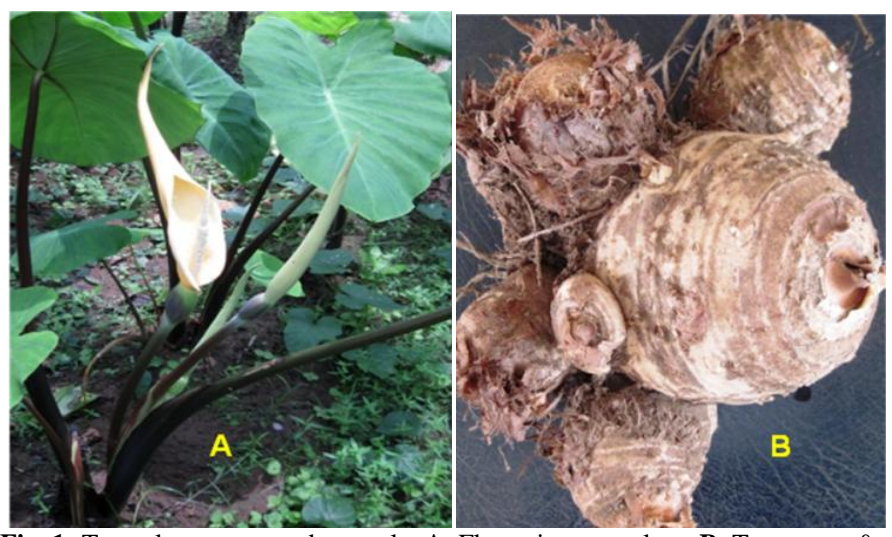

Fig. 1: Taro plant, corm and cormels. A: Flowering taro plant, B: Taro corm \& cormels.

The mucilage of taro has generated some degree of interest probably because they prove useful as binders for pills [43-46]. Pills made with the mucilage of taro dissolve as fast as or faster than pills prepared with acacia gum [44]. Taro corm is low in fat and protein; however, the protein content of taro corm is slightly higher than that of yam, cassava, sweet potato and potato [16]. Another unique food product of taro is the typical Hawaiian food called 'poi'. It is prepared by boiling and pounding taro corms to a porridge-like consistency and allowing it to ferment naturally. Among the indigenous microorganisms present is the predominant acid-producing species of Lactococcus lactis $(95 \%)$ and Lactobacilli (5\%). As the $\mathrm{pH}$ of the poi falls after three to four days these organisms are succeeded by a variety of yeasts contributing to the typical flavor of the product. Poi is also reported to contain significantly more of these bacteria per gram than yoghurt, implying that it is suitable for use in medical nutrition therapy and also shows promise in infants with allergies or failure-to-thrive [47]. The fact that poi is easily digested due to the small size of the starch granules may benefit certain health conditions involving the gastrointestinal tract [48-49]. In addition, lack of gluten in poi has been reported to be the reason for its suitability as an ideal substitute for cereals in patients with celiac disease especially among Caucasians than Asians [50]. Poi may also have beneficial role in medicinal conditions shown to improve with the use of fermented dairy products. They include diarrhea, gastroenteritis, irritable bowel syndrome and inflammatory bowel disease (Crohn's disease and ulcerative colitis), cancer, depressed immune function, and inadequate lactase digestion [47]. Taro is also used as a traditional medicine; its root extracts is used to treat rheumatism and acne, while the leaf extracts is used for blood clotting at wound sites, and for neutralizing snake poison and also as a purgative medicine [3]. In addition, taros mucilage has potential usefulness as an emulsifying, thickening and smoothing agent for creams, suspensions and other colloidal food preparations. Thus, the extraction of this gum-like substance would also alter the properties of taro products and reduce their thickness and viscosity [51]. Moreover, the alcohol yield of taro is lower than that of cassava and cereal crops but higher than that of sugarcane and sweet sorghum (Table 2). The accepted starch-toalcohol conversion ratio is about $1.67 \mathrm{~kg}$ of starch to 1 litre of alcohol, and in the USA, alcohol production cost from taro was considered similar to cassava or sugarcane and estimated to be $\$ 0.15$ per litre in 1978 in comparison to ethanol production from corn at $\$ 0.11$ per litre [2]. This is encouraging and considerable as a practical approach in realizing its potential as an industrial crop (Table 2). The small size of taro starch granules (about one-tenth of the size of maize starch granules) also makes them superior to other starches for the production of biodegradable plastics. Despite their contributions as animal feed, renewable energy source and industrial raw material, the development of agro-industries based on aroids as major inputs remains a theoretical concept contrary to several positive indicators from research and development [51].

Table 2: Estimated alcohol yield per tonne (wet weight) and cropping cycle for selected crops.

\begin{tabular}{ccc}
\hline Crop & Alcohol yield $\left(\right.$ litre. $\mathbf{t}^{\mathbf{1}}$ ) & Cropping cycle (months) \\
\hline Taro & 142 & $9-15$ \\
Sweetpotato & 142 & 5 \\
Sugarcane & 67 & $10-12$ \\
Sweet sorghum & 76.7 & 4 \\
Cassava & 180 & 12 \\
Corn & 385 & 3.5 \\
Spring wheat & 368 & 4 \\
Grain sorghum & 389 & 3.5 \\
\hline
\end{tabular}

Modified from Wang, 1983.

\section{THE CHALLENGE OF TARO PRODUCTION IN NIGERIA}

Cocoyams (taro and tannia) are an important group of tropical root crops providing energy for over 500 million people worldwide, mostly in the tropics [52]. Between 1970 and 1980 cocoyams were among the third most consumed staple food crops in Nigeria, during which it was celebrated yearly with a festival called "Ede Oye" in Nimo, Njikoka LGA, Anambra State, Nigeria and other states in the Southern parts of our country. There are two major edible cultivars in Nigeria, Colocasia esculenta also known as taro and Xanthosoma sagittifolium which is commonly referred to as tannia. Presently, Nigeria occupies the number one position as the world's foremost producer of cocoyams. According to FAO, [53], the average production figures for the past five years in Nigeria is 3,743,200 $\mathrm{mt}$ harvested from an average land area of 661,800 ha. In 2004 alone, Nigeria accounted for $35.5 \%$ of the World's total production of cocoyam [53], although none has ever made it to the International trade market. Ironically, about $72 \%$ of cocoyam produced in Nigeria is known to be consumed as food locally, the balance is often wasted through postharvest rot. Production of cocoyam has not been given priority attention in many countries probably because of its inability to earn foreign 
exchange as well as its unacceptability by some developed countries for both consumption and for research funding. Table 3 shows the major producers of taro globally which is largely dominated by the West African countries. World production of taro in 2007 was estimated at about 12 million metric tonnes of which 9.5 million tonnes were produced in Africa while 2 million were produced in Asia. Its global production increased steadily from 2001-2008 peaking at 12,242,303 tonnes before falling to 9,554,121 tonnes in 2009 and declining further to 9,006,116 tonnes in 2010. It is estimated that West African countries alone consumed 4 million tonnes of taro in 2010 [54]. Table 4 also indicates the production trends in terms of value and tonnes of top 20 cocoyam producers in the world. Nigeria is the leading producer, followed by Ghana with production capacity of $5,387,000$ and 1,688,330 tonnes respectively compared to Papua New Guinea and Guinea in 285,000 and 31,200 tonnes respectively [55].

Table 3: Global production of taro, 2010.

\begin{tabular}{cc}
\hline Top producers & Tonnes \\
\hline World & $9,006,116$ \\
Nigeria & $2,593,860$ \\
China & $1,768,512$ \\
Cameroon & $1,470,000$ \\
Ghana & $1,354,800$ \\
Papua New Guinea & 271,100 \\
\hline
\end{tabular}

Source: McGregor, 2010

Table 4: Top 20 producers of cocoyam, ranked by production.

\begin{tabular}{ccc}
\hline Country & $\begin{array}{c}\text { Production value } \\
\text { (USD 1,000) }\end{array}$ & $\begin{array}{c}\text { Production } \\
\text { (tones) }\end{array}$ \\
\hline Nigeria & 554,968 & $5,387,000$ \\
Ghana & 173,931 & $1,688,330$ \\
China & 160,558 & $1,638,592$ \\
Cameroon & 98,899 & $1,200,000$ \\
Papua New Guinea & 29,360 & 285,000 \\
Madagascar & 17,307 & 240,000 \\
Japan & 15,513 & 179,700 \\
Egypt & 13,698 & 151,971 \\
Rwanda & 11,394 & 110,607 \\
Philippines & 10,400 & 115,956 \\
Central African Republic & 10,302 & 100,000 \\
Thailand & 8,087 & 78,500 \\
Cote d' Ivore & 7,717 & 93,639 \\
Fiji & 7624 & 74,009 \\
Burundi & 6,825 & 66,250 \\
Gabon & 5,988 & 58,125 \\
Solomon Islands & 5279 & 56,000 \\
Liberia & 4,532 & 44,000 \\
Guinea & 3,090 & 30,000 \\
\hline Souratic & 2,892 & 31,200 \\
\hline 2008 & &
\end{tabular}

Source: FAO, 2008

Post-Nigerian civil war research on root and tuber crops started and concentrated on the improvement of cassava, sweetpotato and yams. It was later in 1973 that cocoyam research and improvement was initiated at the National Root Crops Research Institute (NRCRI) Umudike, Umuahia, Nigeria. Towards the late 1980s the fortunes of cocoyam progressively nosedived. Challenges mitigating profitable cocoyam farming in the last three decades in Nigeria include; scarcity of quality planting materials, low multiplication ratio, low genetic base and lack of improved varieties, lack of effective storage facilities and poor shelf-life of corms and cormels, declining soil fertility, as well as the incidences of pests and diseases. Worried by these setbacks NRCRI Umudike, which has the national mandate for research and improvement of root and tuber crops in Nigeria among other key functions, conceived in 2007 the "Cocoyam Rebirth Initiative" as a strategy to reverse the moribund cocoyam production and create awareness on the nutritional/medicinal and economic potentials of the crop. To worsen the situation, the arrival of taro leaf blight (TLB) in Nigeria in 2009 with its severity and wide spread nature, practically crippled cocoyam production in the country (Fig. 2A \& B). Furthermore, the old system of multiplication through vegetative propagation further worsened production output as farmers continued replanting infected planting materials into new areas. Usually the planting materials used for planting are small corms and cormels sliced from large corms and cormels respectively and huli stem cuttings.

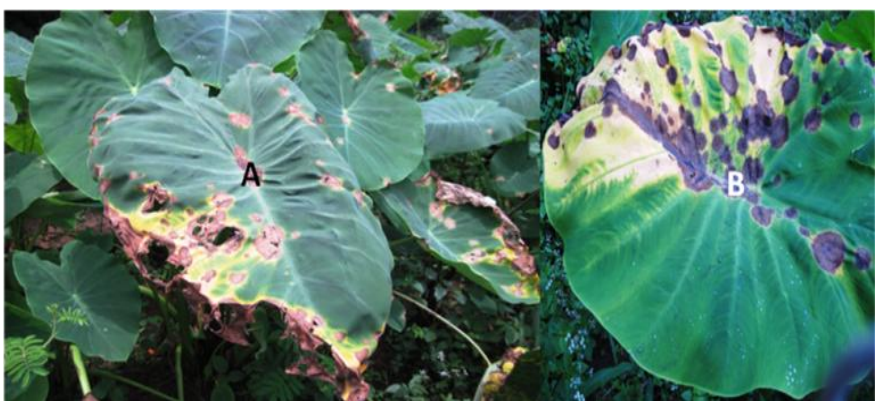

Fig. 2: Taro leaf blight. A: Taro field infested with pythophthora colocasae. B: Taro leaf showing areas of decay with multiple lesions caused by pythophthora colocasiae.

These corms and cormels are also edible, meaning competition between what to be planted and what to be consumed. It is not clear why cocoyam is unpopular in comparison with some other root and tuber crops in Nigeria. Arguably, it appears however, to be more expensive than both yam and cassava. Regrettably research in cocoyam production, processing, marketing and consumption appears to be neglected probably because of apparent lack of interest by the developed nations. Onwueme, [56] noted that the major reason for the relative obscurity of cocoyams in Nigeria is because its cultivation is restricted to the South Eastern, South South and South Western parts of the country mainly due to ecological reasons. He further adduced reasons for casualness in cocoyam cultivation to be historical. In the South Western Nigeria where Xanthosoma is predominant, the crop gained widespread use as a shade crop for young cocoa seedlings in the plantation. Moreover in the past, cocoyams were mostly grown by women [57]. Another factor is that cocoyams are usually consumed shortly after harvest because of storage difficulties. Ironically, cocoyam planting in Nigeria is done with the edible corms and occasionally with cormels. This practice creates direct competition between what is to be eaten and what is to be reserved for planting. Furthermore, the introduction and popularization of cassava, maize and rice may have 
contributed to the rapid decline in the acceptability of cocoyams as food. Ezedinma [58] presented a pathetic paper on cocoyam research in Nigeria. He noted that at the $4^{\text {th }}$ symposium of the International Society for Tropical Root Crops held in Cali, Columbia in 1976, only 3 scientific papers were presented on cocoyam compared to 35 on cassava, 11 on potato and 5 on yams. At the First Triennial symposium of the International Society for Tropical Root Crops, Africa Branch held in Ibadan in 1980, only 6 scientific papers were presented on cocoyam compared to 32 on cassava and 11 on yams. Similarly, at the society's symposium in Douala, Cameroon in 1983, there were some 6 papers on cocoyam while cassava had 27 and yam 14. Recently at the $16^{\text {th }}$ International Society for Tropical Root Crops (ISTRC) held in Abeokuta in 2011, only 23 scientific papers were presented on cocoyam compared to 95,45 and 60 for cassava, sweetpotato and yam respectively. A similar trend was also observed at the same ISTRC symposium in Accra, Ghana in 2013 where only 16 scientific papers were presented on cocoyam against 111, 41, 43 for cassava, sweetpotato and yam respectively. Although there was a relative improvement in 2011 and 2013 compared to 1973, 1980 and 83 , but a cursory look at the entire picture clearly implies that the totality of the published scientific work on cocoyam is insignificant compared with those of other root and tuber crops. These may be the jinx besetting cocoyam production and productivity in Nigeria.

Challenged by the scourging effects of diseases on our farms, NRCRI Umudike desperately addressed this problem through wide scale fungicide spraying programme, and cultural management control which yielded minimal positive results. To further broaden our cocoyam gene pool, NRCRI Umudike in 2010 in collaboration with European Union took delivery of 50 exotic accessions of cocoyam from the Pacific Island. Some of them were resistant to taro leaf blight (TLB) while some were tolerant. Among the objectives of the project were; to broaden the narrow gene pool of cocoyam in our Institute, to enhance breeding of resistant varieties to TLB and to disseminate the TLB resistant varieties to farmers through their involvement in participatory breeding. These cultivars have been adapted, multiplied in our plant tissue culture unit, acclimated and is undergoing field evaluation. Currently, crossing of the resistant varieties with our local land races is on. Preliminary results of the crosses have shown that some of the progenies have some levels of resistance to TLB. The approach is quantitative, cumulative and progressive in both its inheritance and its effects. Thus, the possibility to improve the level of resistance in our newly developed resistant clones of cycle 1 crosses has emboldened NRCRI Umudike in its renewed efforts to wrestle down the scourge of TLB in our country. However, despite the numerous advantages of cocoyam over other root and tuber crops, sustainable cocoyam production in Nigeria is still a mirage. This challenge could be reversed through effective research and appropriate funding. The following strategic approaches could help reposition and enhance production and multiplication of healthy cocoyam planting materials:
- Awareness creation on the nutritive/medicinal values and diversities of food forms of cocoyam.

- Non-recycling of planting materials through vegetative propagation as it encourages accumulation and dissemination of pathogens. Such a practice translates to yield decline with time and may have accounted for the reported yield decline of $11 \%$ in our national production figures between 2000 and 2004 [59].

- Generation of "clean" planting materials through in vitro meristem tip culture and their subsequent multiplication in tissue culture will not only stem the disease but increase yield as well.

- A breakthrough in conventional breeding, mutation breeding, somaclonal variation is timely to introduce cultivars with more desirable agronomic traits. This approach will also help to broaden the current narrow gene pool.

- Participatory plant breeding is another aspect that could improve the level of horizontal (sustainable) resistance to TLB which is based on broad gene combinations as a result of many different resistance mechanisms.

- Production should be targeted towards exporting the produce to the international trade market, to generate foreign exchange. Strategically, this will stimulate production and encouragement on the part of the farmers.

- Development of superior species through cross breeding with exotic disease resistant species from other countries of the world.

- Development of improved technology packages for increased yields and productivity

- Development of appropriate control measures to eliminate field and storage losses due to TLB and other storage rot organisms.

- Development and deployment of sustainable storage facilities to prolong the shelf-life of cocoyam after harvest.

- Diversification of appealing and acceptable cocoyam recipes as well as create more industrial uses for cocoyam.

- Availability of research funds to enable scientists engage in result oriented research.

Addressing all these will place cocoyam crop on its supposed enviable path to contribute effectively to the food supply and to the economy of all producing and consuming nations of the world.

\section{CONCLUSIONS}

The nutritional and health benefits of taro are compressed in this paper. Its uses as an industrial crop was also highlighted. There exist possibilities of processing taro into different types of 
products. To maintain stability and to offer convenience and ease in preparation, preparation into dehydrated forms is encouraged. Intermediate products of taro such as taro flour and dried slices could be prepared and further extruded into convenient ready-touse stable forms such as taro rice, noodles, macaroni and spaghetti. Moreover, the outlined strategic approaches will address most of the problems associated with taro cultivation, yield and postharvest losses.

\section{REFERENCES}

1. Jones DA. Why are so many food plants cyanogenic? Phytochemistry. 1998; 47(2):155- 162.

2. Wang JK. Taro: A Review of Colocasia esculenta and its potential. Honolulu: University of Hawaii; 1983.

3. Thinh NT. Cryopreservation of germplasm of vegetatively propagated tropical monocots by vitrification. Doctoral Dissertation, Kobe University; 1997.

4. Sunitha S, Ravi V, George J, Suja G. Aroids and Water Relations: An Overview. Journal of Root Crops. 2013; 39(1):1021.

5. Lebot V. Tropical root and tuber crops: Cassava, sweetpotato, yams and aroids. CABI, Wallingford, United Kingdom; 2009.

6. Mohankumar CR, Sadanandan N. Growth and rooting pattern of taro (Colocasia esculenta (L) Schott). Journal of Root Crops. 1990; 16: 61-63.

7. Pacific Root Crops. Pacific food security Toolkit. Building resilience to climatic change-root crop and fishery production; 2010.

8. Sunel LA, Arditi JC. Phsiology and Phytochemistry. In: Taro, a review of Colocasia esculenta and its potentials. Wang, J.K. (Ed.). University of Hawaii Research, Honolulu Hawaii; 1983, p. 34-139.

9. Onwueme I. Taro cultivation in Asia and the Pacific. Food and Agriculture organization of the United Nations Regional office for Asia and the Pacific Bangkok, Thailand, 1999.

10. Castro GR. Studies on cocoyam (Xanthosoma spp.) in Nicaragua with emphasis on Dasheen mosaic virus. Doctoral Thesis, Swedish University of Agricultural Sciences Uppsala; 2006.

11. Addai IK, Scott P. Influence of bulb sizes at planting on growth and development of the common hyacinth and the lilly. Agriculture and Biology Journal of North America. 2011; 2(2): 298-314.

12. Osundare B. Effect of fertilizer types and varying population on the performance of cocoyam. 2007; 5(1): 7pp.

13. Ndon BA, Ndulaka NH, Ndaego NU (2003). Stabilization of yield parameters and some nutrient components in cocoyam cultivars with time in Uyo, Southern Nigeria. Global Journal of Agricultural Science. 2003; 2:74-78.

14. Nwufo MI, Atu UG. Postharvest rots of cocoyam in Nigeria. Proceedings of the $1^{\text {st }}$ National workshop on cocoyam. NRCRI, Umudike, Umuahia, Nigeria; 1987.

15. Ivancic A. Breeding and genetics of taro (Colocasia esculenta (L) Schott (pp.1-97). Ministry of Agriculture and lands, Solomon
Islands UNDP, Food and Agriculture Organizations of the United Nations; 1992.

16. Deo PC, Tyagi AP, Taylor M, Becker DK, Harding RM. Improving taro (Colocasia esculenta var. esculenta) production using biotechnological approaches. South Pacific Journal of Natural Science. 2009; 27:6-13.

17. Wilson JE. Agro Facts, taro breeding, IRETA Publication No: 3/89, 1990.

18. Tyagi AP, Taylor M, Deo PC. Seed germination and seedling development in taro (Colocasia esculenta). The South Pacific Journal of Natural Science. 2004; 22: 61-65.

19. Revill PA, Jackson GVH, Hafner GJ, Yang I, Maino MK, Dowling MC, Devitt, LC, Dale JL, Harding RM. Incidence and distribution of viruses of taro (Colocasia esculenta) in Pacific Island Countries. Australian Plant Pathology. 2005; 34: 327-331.

20. Jackson GVH, Ball EA, Arditi J. Tissue culture of taro (Colocasia esculenta) (L.) Schott). Journal of Horticultural Science. 1997; 52:373-382.

21. Tuia VS. In vitro multiplication of taro (Colocasia esculenta var. esculenta L. Schott), Ministry of Agriculture. University of the South Pacific, 1997.

22. Yam TW, Ichihashi S, Arditti J. Callus growth and plantlet regeneration in taro, Colocasia var. esculenta (L.) Schott (Araceae). Annals of Botany. 1991; 67:317-323.

23. Verma VM, Cho JJ, Aikne J, David J. High frequency plant production of taro (Colocasia esculenta (L.) Schott) by tissue culture. Paper presented at the proceedings for the $4^{\text {th }}$ International Crop Science Congress, Brisbane, Australia, 2004.

24. Deo PC. Somatic embryogenesis and transformation in taro (Colocasia esculenta var. esculenta). PhD Thesis. The University of the South Pacific, Suva, Fiji, 2008.

25. Aguado-Santacruz GA, Rascón-Cruz Q, Cabrera-Ponce JL, Martinez-Hernandez A, Olalde-Portugal V, Herrera-Estrella L. (2002). Transgenic plants of blue grama grass, Bouteloua gracilis (H.B.K) Lag. Ex. Steud., from microprojectile bombardment of highly chlorophyllus embryonic cells. Theoretical and Applied Genetics. 2002; 104:763-771.

26. Sahrawat AK, Becker D, Lötticke S, Lörz H. Genetic improvement of wheat via alien gene transfere, an assessment. Plant Science. 2003; 165:1147-1168.

27. ul-Haq I. Callus proliferation and somatic embryogenesis in cotton (Gossypium hirsutum L.). African Journal of Biotechnology. 2005; 4: 206-209.

28. He X, Miyasaka S, Fitch MM, Zhu YJ, Moore PH.Transformation of taro Colocasia esculenta) with a rice chitinase gene. In vitro Cellular and Developmental BiologyPlant.2004; 40: 2104.

29. He X, Miyasaka S, Fitch MM, Zhu YJ, Moore PH, Zhu, YJ. Agrobacterium tumefaciens-mediated transformation of taro (Colocasia esculenta (L.) Schott) with a rice chitinase gene for improved tolerance to a fungal pathogen Sclerotium rolfsii. Plant Cell Reports. 2008. 27: 903-909.

30. Orji KO, Ogbonna PE, Eze CE. Evaluation of growth and yield responses of some taro (Colocasia esculenta) cultivars to plant spacing on the plains s to plant spacing on the plains of Nsukka, 
Southeastern Nigeria. International Journal of Science and Research (IJSR). 2012; 3(9): 1-5.

31. Standal BR. Nutritive value of taro. In: J.K.Wang, (ed). Taro: A review of Colocasia esculenta and its potentials. Honolulu, Hawaii: University of Hawaii press; 1983, p. 141-147.

32. Kaushal P, Kumar V, Sharma HK. Utilization of taro (Colocasia esculenta): a review. Journal of Food Science and Technology. 2015.

33. Amon AS, Soro RY, Koffi PKB, Dué EA, Kouamé LP. (2011). Biochemical properties of flour from Ivorian Taro (Colocasia esculenta $\mathrm{Cv}$. Yatan) corm as affected by boiling time. Advance Journal of Food Science and Technology. 2011; 3(6):424-435.

34. John KS. Soil fertility management strategies in edible yams and aroids: A review. Journal of Root Crops. 2011; 37(1): 3-18.

35. Nelson SC. Dasheen mosaic of edible and ornamental aroids. Plant diseases. 2008; 1-9.

36. Lape IM. Nutritional quality of yam (Dioscorea dumetorum and Dioscorea rotundata) flours for growing rats. Journal of Science and Food Agriculture. 1994; 66: 447-455.

37. Cho JJ, Yamakawa RA, Hollyer J. Hawaiin kalo, past and future. Sustainable Agriculture. 2007; 1-8.

38. Anigbogu NM. Taro as a substitute for corn in broiler rations. IITA Tropical Root and Tuber Crops Bulletin. 1995; 8(2): 89.

39. IRETA. Postharvest systems for improved quality of Pacific Island export taro. IRETA's South Pacific Agricultural News. 1997; p.7.

40. Huang AS, Titchenal CA, Meilleur BA. Nutrient composition of taro corms and breadfruit. Journal of Food Composition and Analysis. 2001; 13: 859-864.

41. Dastidar SG. Colocasia esculenta: An account of its ethnobotany and potentials. MSc thesis. The University of Texas at Austin; 2009.

42. Food and Agriculture Organization of the United Nations (FAO). Neglected Crops 1492 from a different perspective. FAO plant production and protection series. 1994: Series No. 26.

43. Ferguson LR. Adsorption of a hydrophobic mutagen to dietary fibre from taro (Colocasia esculenta), an important food plant of the South Pacific. Nutrition and Cancer. 1992; 17: 85-95 [PubMed: 1315430].

44. Opara LU. Edible Aroids: Postharvest operations. Inpho-Postharvest compendium. 2003; 1-28.

45. Huang As, Lam SY, Nakayama TM, Lin H. Microbiological and chemical changes in poi stored at $20^{\circ} \mathrm{C}$. Journal of Agriculture, Food and Chemistry. 1994; 42: 45-48.

46. Hernandez-Uribe JP, García-Suárez FJ, Gutiérrez-Meraz F, Rodriguez-Ambriz SL, Bello-Perez LA. By-products derived of the starch isolation from tubers. Physicochemical and functional properties. Journal of Food, Agriculture and Environment. 2014; 12(1): 43-46.
47. Brown AC, Valiere MS. The medicinal uses of poi. Nutrition and Clinical Care. 2004;7(2):69-74.

48. Abbott IA, Hawaii L. Traditional Hawaiian uses of plants. Honolulu, Bishop Museum Press; 1992.

49. Ferguson LR, Roberton AM, Mckenzie RJ, Watson ME, Harris PJ. Adsorption of a hydrophobic mutagen to dietary fibre from taro (Colocasia esculenta) an important food plant of the South Pacific . Nutrition and Cancer. 1992; 17:85-95.

50. Goldin BR. Health benefits of probiotics. British Journal of Nutrition. 1998; 80: S203-S207 [PubMed: 9924285].

51. Food and Agricultural Organization of United Nations (FAO). Root crops. Spore; 2003, 101:1.

52. Lyonga SN, Nzietchueng S. Cocoyam and the African food crisis. Institut de la recherché agronomique. Buea. Cameroon; 1987.

53. FAO. Food and Agricultural Organization of the United Nations FAOSTAT, Statistical Database, FAO, Rome; 2005.

54. McGregor A, Afeaki P, Armstrong J, Hamilton H, Hollyer J, Masambu R, Nalder K. Pacific Island Taro market access scoping study. Facilitating Agricultural Commodity Trade (FACT) project, the Secretariat of the Pacific Commodity (SPC); 2011.

55. Food and Agricultural Organization of United Nations (FAO). Publication report. (http://www.fao.org); 2008.

56. Onwueme IC. Strategies for increasing cocoyam (Colocasia and Xanthosoma spp) in Nigerian Food Basket. In: Arene, O. B., Ene, L.; 1987.

57. Olagunji FI, Adesiji GB. Impact of Agricultural extension services on cocoyam production in Ogun State, Nigeria. Journal of Agricultural and Food Information. 2011; 12(3-4): 294-303.

58. Ezedinma FOC. Prospect of cocoyam in the food system and economy of Nigeria. Cocoyams In Nigeria: Production, Storage, Processing and Utilization. Proceedings of the $1^{\text {st }}$ National Workshop on Cocoyam. NRCRI, Umudike, Nigeria; 1987.

59. Food and Agricultural Organization (FAO). FAOSTAT Tbase http:www.fao.org; 2001, 2004.

\section{How to cite this article:}

Ubalua AO, Ewa F, Okeagu OD. Potentials and challenges of sustainable taro (Colocasia esculenta) production in Nigeria. J App Biol Biotech, 2016; 4 (01): 053-059. DOI: 10.7324/JABB.2016.40110 